\title{
Microbial Dynamics and Fertility Characteristics in Compost from Different Waste and Maturation Processes
}

\author{
A. Abril*,a ${ }^{*}$ L. Noe ${ }^{\mathrm{a}}$, M.F. Filippini ${ }^{\mathrm{b}}$, M. Cony ${ }^{\mathrm{c}}$ and L. Martinez ${ }^{\mathrm{d}}$ \\ ${ }^{a}$ Facultad de Ciencias Agropecuarias, Universidad Nacional de Córdoba. Cc 509, 5000, Córdoba, Argentina; ${ }^{b}$ Facultad \\ de Ciencias Agrarias. Universidad Nacional de Cuyo, Chacras de Coria, 5505, Mendoza, Argentina; ${ }^{c} I A D I Z A$ CCT -

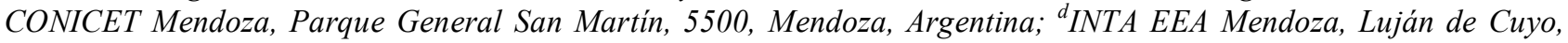 \\ 5507, Mendoza, Argentina
}

\begin{abstract}
We evaluated the abundance of microbial functional groups involved in compost fertility, and the chemical parameters of maturity and quality most commonly analyzed in compost products. We employed compost produced using the same hydrolytic stage and two maturation processes (with and without earthworms) and with different organic wastes. Our aim was to propose a valid tool for measuring the quality standards of compost fertility from a microbial perspective. The products obtained from both maturation processes were highly variable in their chemical and biological composition (without following a general pattern). Because the results are so heterogeneous, proposing a microbial population as universal indicator of the degree of compost fertility is very difficult. However, the microbial community structure might be used as a maturity index, because the products that best fulfilled the chemical stability parameters were those with lowest number of populations in its community.
\end{abstract}

Keywords: Microbial community structure; vermicompost; humification indices; stability/maturation parameters; manures.

\section{INTRODUCTION}

Compost amendments are widely used in agriculture because they contribute to alleviating two important environmental issues: loss of soil fertility and accumulation of organic residues produced by agricultural, household and industrial activities [1]. Information about the technology of compost production and standards regulating compost use and quality is abundant in the literature [2-4]. Composting techniques include windrow-composting (a thermophilic hydrolytic stage plus a mesophilic maturation stage), vermicomposting (both mesophilic stages with earthworms) and a combination of both techniques. The latter method aims at eliminating pathogens (sanitization) through heat treatment and further use of earthworm activity to improve product stabilization $[5,6]$.

As composting is essentially a microbial process, the chemical composition of waste materials define microbial activity and therefore compost quality. For example, organic residues with high structural compounds (cellulose and lignin) can only be degraded slowly by very specific groups of microorganisms, thereby producing compost with a high content of stabilized organic matter (OM). By contrast, waste materials with high amount of soluble compounds are metabolized very rapidly by any group of microorganisms, generating compost with a low level of stable OM $[7,8]$. Accordingly, the waste materials are usually mixed together

\footnotetext{
*Address correspondence to this author at the Facultad de Ciencias Agropecuarias, Universidad Nacional de Córdoba. Cc 509, 5000, Córdoba, Argentina; Tel/Fax: 54351 4334105/03;

E-mail: aabril@agro.unc.edu.ar
}

with the aim of standardizing some variables, thus facilitating the speed and efficacy of the process. $\mathrm{C} / \mathrm{N}$ ratio is usually standardized (approximately 30/1), thus ensuring the balance between $\mathrm{C}$ needed for metabolic energy and $\mathrm{N}$ used for cell synthesis in microorganisms [9].

The compost quality (degree of compost maturity) has been extensively analyzed and several physical, chemical and biological indicators of OM stability have been proposed with inconsistent results $[2-4,10,11]$. For example, Wang et al. [12], reported that often there is no correlation between indicators of compost maturity and plant fertility parameters (size and chemical composition of seedlings), and Benitez et al. [3] did not find correlation between OM stabilization and microbial activity. The lack of consistency among studies may be attributed to the fact that biological indicators of maturity include general parameters (biomass, respiration, enzymatic activity, and taxonomic and functional aspects of $\mathrm{C}$ degradation). These general parameters assume the microbial community as a unique functional entity and in consequence do not represent the complexity of microbial processes that occurred during composting $[2,10]$.

Microbial functional groups, however, are extensively used as soil fertility indicators because they are highly sensitive to climatic and management conditions and they accurately represent entire biological processes. For example, dynamics of $\mathrm{N}$ availability can be clearly established by determining abundance of nitrifier and $\mathrm{N}$-fixing microorganisms [13]. Moreover, because degradation of organic residues results from interrelated microbial processes, fertility depends on a balanced abundance of the different functional 
groups. Therefore, the studies are usually focused on the community structure of microbial functional groups [14].

Information on the dynamics of microbial groups during composting processes is scarce [15], however, knowing the effect of heat on microbial populations during the sanitization phase and the degree of microbial recolonization at maturation stage is very important [9]. The latter aspect may generate large differences between processes with or without earthworms because it is well known that earthworms affect microbial structure and activity through inoculum dispersal, grazing, gut passage and aggregate formation [16]. It should be noted that in most countries compost quality standards do not include microbial parameters of soil fertility. Compost quality standards that regulate aspects related to microorganisms refer exclusively to the presence of pathogens because many of the wastes used for composting are usually hazardous to human health $[1,17]$.

We evaluated the abundance of microbial functional groups involved in compost fertility and the chemical parameters of maturity and quality commonly analyzed in compost products. We employed compost produced using a single thermophilic hydrolytic stage and two maturation processes (with and without earthworms) and with different organic wastes available in Mendoza (Argentina). Our aim was to propose a valid tool for measuring the quality standards of compost fertility from a microbial perspective.

\section{MATERIALS AND METHODS}

\section{Study Area and Materials}

Organic waste and compost production methods employed in this work were the ones most commonly used in the irrigation area of Mendoza, Argentina (33 $00^{\prime} \mathrm{S} ; 68^{\circ} 38^{\prime}$ $\mathrm{W})$. The climate in Mendoza is arid, with very high temperatures in summer (average $25^{\circ} \mathrm{C}$ ) and very low values in winter (average $10^{\circ} \mathrm{C}$ ), and a mean annual rainfall of $250 \mathrm{~mm}$. Due to dry condition, snows in the area are insignificant. Organic wastes used were: solid grape waste (Gr), olive press cake $(\mathrm{O})$, poplar sawdust and shaving (W), horse manure (with bed of poplar shaving) (HL), goat manure (G), and chicken manure (with bed of rice bran) (ChL).

\section{Analysis and Mixing of Organic Wastes}

Before composting, we analyzed total $\mathrm{C}$ by the wetdigestion method [18], and total $\mathrm{N}$ (micro-Kjeldahl method) in organic wastes, to calculate $\mathrm{C} / \mathrm{N}$ ratio (Table 1). Some wastes were then mixed in different proportions to standardize the $\mathrm{C} / \mathrm{N}$ ratio at 30 : a) chicken manure + poplar sawdust and shaving $(\mathrm{ChL}-\mathrm{W}), \mathrm{b})$ horse manure $(\mathrm{HL}), \mathrm{c})$ goat manure + poplar sawdust and shaving $(\mathrm{G}-\mathrm{W}), \mathrm{d})$ goat manure + olive press cake (G-O), e) chicken manure + olive press cake $(\mathrm{ChL}-\mathrm{O})$, and $\mathrm{f})$ solid grape waste $(\mathrm{Gr})$.

\section{Composting Methods}

Composting of waste materials consisted of a single hydrolytic phase and two maturity processes: with earthworms (vermicomposting) and without earthworms (windrowcomposting). The six waste treatments were arranged in piles (1.50 m high x $30 \mathrm{~m}$ long) outdoors on July 2004. Temperature and humidity in the pile were maintained at $50{ }^{\circ} \mathrm{C}$ and
$50 \%$, respectively, by means of regular irrigation and aeration. After 60 days, each pile was divided in half. One half was left to continue with the maturation process in the same pile (WC) and the other half was placed in vermicomposting beds (VC) for maturation. The beds $(20 \mathrm{~m}$ long, $1 \mathrm{~m}$ wide, and $0.35 \mathrm{~m}$ high) were placed directly on the ground, inoculated with approximately 30000 worms $/ \mathrm{m}^{2}$ (Eisenia foetida) per bed, and watered so as to maintain humidity at approximately $80 \%$. WC treatments were harvested after 120 days (November 2004) and VC after 180 days (January 2005), 120 days after earthworm addition. Both products were sieved $(2 \mathrm{~mm})$ and packed.

\section{Sampling Design}

Samples were taken at: a) the hydrolytic stage, when temperature of the thermophilic phase started to decrease (sanitised output), at approximately 20-30 days, depending on the treatment, and b) at product harvest (120 days for WC and 180 days for VC). The first sampling consisted of three samples $(250 \mathrm{~g})$ taken at about $70 \mathrm{~cm}$ from the top of each pile (approximately the middle of the pile). At the second sampling, three samples of the sieved final products $(250 \mathrm{~g})$ were taken at random. All samples were taken with sterile steel corers.

\section{Analytical Determinations}

Abundance (expressed as log of bacteria number per $g$ of material) of microbial functional groups responsible for waste transformation and abundance of microorganisms as indicators of health risk were recorded for all samplings. Counts were performed using the following techniques: a) the most probable number in liquid culture media specific for the following functional groups: ammonifiers (mineral media plus asparagine); nitrifiers (mineral media plus ammonium sulphate); and cellulolytics (mineral media plus cellulose strips) [19], and b) agar plate methods for N-fixing bacteria ( $\mathrm{N}$-free basal medium) [20] and saccharolytic fungi (potato dextrose agar) [19]. Samples were homogeneized in physiological solution in order to extract microorganisms. The cultures were incubated at $28{ }^{\circ} \mathrm{C}$ for 5 to 21 days, depending on the functional group. Health risk bacteria (Escherichia coli and Salmonella spp.) were determined following USEPA's recommended methodology [21].

In samples taken at the hydrolytic stage the following physical and chemical characteristics were analyzed: a) water content by gravimetric method; b) $\mathrm{pH}(\mathrm{w} / \mathrm{v} 1: 1)$; c) electrical conductivity (w/v 1:5); d) total organic C (TOC) by the wet-digestion method of Walkley and Black modified for plant material [18]; e) soluble organic $\mathrm{C}$ by the Walkley and Black method, previously extracted with water at $80{ }^{\circ} \mathrm{C}[22]$; f) lignin and cellulose content by enzymatic gravimetric methods [23]; g) total N (TN) by micro-Kjeldahl method; h) ammonium and nitrate by colorimetric methods; i) total $\mathrm{Ca}$ and $\mathrm{Mg}$ by compleximetric titration methods; j) total $\mathrm{P}$ by colorimetric methods, $\mathrm{k}$ ) total $\mathrm{Na}$ and $\mathrm{K}$ with flame photometric detectors and 1) heavy metals $(\mathrm{Pb}, \mathrm{Cd}, \mathrm{Cu}, \mathrm{Zn}, \mathrm{Cr}$, Ni), by Atomic Absorption Spectrophotometry [24]. The same parameters were analyzed in harvested products, except soluble $\mathrm{C}$, cellulose and lignin; and the following humic-like substances were included: humic and fulvic acid contents (HA and FA), following Jouraiphy et al. [25]. 


\section{Calculations and Statistical Analyses}

The following maturity indices were calculated: $\mathrm{C} / \mathrm{N}$ ratio, ammonium/nitrate ratio, humification index (HI= $\mathrm{HA}+\mathrm{FA} / \mathrm{OM})$, and polymerization degree $(\mathrm{HT}=\mathrm{HA} / \mathrm{FA})$ [7]. Microbial community structure was also estimated using the proportion (\%) of abundance of each functional group relative to the total group analyzed.

An analysis of variance (ANOVA) was conducted to compare the effect of the different treatments. To compare microbial abundance between sampling dates, percentages of variation with respect to the hydrolytic stage were calculated and analyzed with ANOVA, using the function $\mathrm{y}=\arcsin \sqrt{\mathrm{y}}$. Comparison of means was performed with Tukey test. Correlation analysis was performed to test for linear relationships between variables using the Pearson test.

\section{RESULTS}

\section{Chemical and Biological Characteristics of Composting Material at the Hydrolytic Stage}

Chemical composition of materials at the hydrolytic stage varied significantly between treatments. Although the $\mathrm{C} / \mathrm{N}$ ratio had been adjusted at 30/1 at the pile preparation stage, at the hydrolytic stage most of the treatments already exhibited a lower $\mathrm{C} / \mathrm{N}$ than at the beginning of the experiment. Similarly, although all the treatments were equally watered to reach $50 \%$ of water content, moisture values in treatments containing olive press cake were below the $50 \%$ level $(\mathrm{G}-\mathrm{O}=$ $47.29 \%$ and $\mathrm{ChL}-\mathrm{O}=47.64 \%$ ). Goat manure + poplar sawdust and shaving (G-W) and solid grape waste (Gr) had the highest and lowest conductivity values, respectively, whereas horse manure (HL) and G-W showed the highest $\mathrm{pH}$ values (Table 2).

TOC content was lowest in chicken manure + poplar sawdust and shaving (ChL-W) and highest in Gr and G-O, whereas soluble $\mathrm{C}$ content in treatments containing olive press cake (G-O and $\mathrm{ChL}-\mathrm{O}$ ) and grape waste ( $\mathrm{Gr}$ ) was significantly lower than in the other treatments (Table 2). The highest total $\mathrm{N}$ value was detected in $\mathrm{Gr}$, although it did not differ statistically from that of ChL-O or G-W, whereas inorganic $\mathrm{N}$ fractions were very high in mixtures containing manure and very low in treatments containing grape waste and olive press cake. High concentrations of $\mathrm{P}$ and bivalent cations (Ca and $\mathrm{Mg})$ were found in $\mathrm{ChL}-\mathrm{W}\left(\mathrm{P}=20.9 \mathrm{~g} \mathrm{~kg}^{-1}\right.$; $\left.\mathrm{Ca}=88.4 \mathrm{~g} \mathrm{~kg}^{-1} ; \mathrm{Mg}=10.1 \mathrm{~g} \mathrm{~kg}^{-1}\right)$, probably because of the mineral-reinforced diet in chickens. By contrast, monovalent cations $(\mathrm{Na}$ and $\mathrm{K})$ were significantly higher in treatment $\mathrm{G}-\mathrm{W}$ and lower in treatments containing industrial waste (Table 2) than in the remaining treatments.

The amount of heavy metals also varied significantly between treatments, except for $\mathrm{Cr}$ and $\mathrm{Ni}$, which were not detected in any of the mixtures. The highest values of $\mathrm{Zn}, \mathrm{Pb}$ and $\mathrm{Cd}$ were found in $\mathrm{ChL}-\mathrm{W}$, and the lowest ones in $\mathrm{Gr} . \mathrm{Cu}$ values were very similar in all treatments, except in mixtures with goat manure (G-W and G-O), which exhibited the lowest values (Table 2 ).

Similar to the differences detected in chemical characteristics, abundance of all microbial functional groups varied significantly among treatments at the hydrolytic stage. Saccharolytic fungi were significantly more abundant in mixtures containing industrial waste ( $\mathrm{G}-\mathrm{O}, \mathrm{ChL}-\mathrm{O}$, and $\mathrm{Gr})$, and ammonifiers were more abundant in treatments containing goat manure (G-W and G-O) than in the remaining treatments. By contrast, treatments containing goat manure yield the lowest amount of $\mathrm{N}$-fixing bacteria (Table 3). As expected, mixtures containing woody residues (ChL-W and GW) showed the highest abundance of cellulolytic microorganisms, whereas nitrifiers were higher in $\mathrm{HL}$ and G-W, which is consistent with the high values of nitrates detected in such treatments (Table 2). After sanitization, no bacteria indicators of health risk (Salmonella spp. and E. coli) were detected in any composting material.

Despite the differences detected in abundance of functional groups, structure of microbial communities in the different treatments was similar. In most cases the population of $\mathrm{N}$-fixers was the dominant one, except in the treatments containing woody residues (ChL-W and G-W), in which cellulolytics were dominant (36 and 30\%, respectively) (Fig. 1a).

\section{Chemical and Biological Characteristics of Windrow Composted Products (WC)}

Products obtained from windrow composting after the maturation stage were highly variable in their chemical composition and all treatments differed significantly in all the parameters analyzed. In general, treatment $\mathrm{Gr}$ exhibited the lowest values of moisture $(27.96 \%)$, conductivity, $\mathrm{pH}$, nitrate, $\mathrm{P}\left(1.1 \mathrm{~g} \mathrm{~kg}^{-1}\right), \mathrm{Ca}\left(12.3 \mathrm{~g} \mathrm{~kg}^{-1}\right), \mathrm{Mg}\left(1.3 \mathrm{~g} \mathrm{~kg}^{-1}\right), \mathrm{K}, \mathrm{Na}$, $\mathrm{Zn}, \mathrm{Pb}$, and $\mathrm{Cd}$, and the highest values of TOC, fulvic acids, ammonium, and $\mathrm{Cu}$ (Table 4). By contrast, treatment ChL-W exhibited the highest values of humid acid content, nitrates,

Table 1. Total Organic $\mathbf{C}$ and $\mathbf{N}$ content and $\mathrm{C} / \mathrm{N}$ Ratio in Starting Materials. TOC: Total Organic C, TN: Total $\mathbf{N}$

\begin{tabular}{|c|c|c|c|}
\hline & TOC $\left(\mathrm{g} \mathrm{kg}^{-1}\right)$ & $T N\left(\mathrm{~g} \mathrm{~kg}^{-1}\right)$ & $\mathbf{C} / \mathbf{N}$ \\
\hline Horse manure, with bed of poplar shaving (HL) & 331.0 & 10.1 & 32.8 \\
\hline Solid grape waste $(\mathrm{Gr})$ & 544.5 & 18.0 & 30.3 \\
\hline Goat manure (G) & 195.9 & 15.1 & 13.1 \\
\hline Chicken manure, with bed of rice bran $(\mathrm{ChL})$ & 174.0 & 20.0 & 8.7 \\
\hline
\end{tabular}


Table 2. Chemical Characteristics of Composting Materials from All Treatments at the Hydrolytic Stage. ChL-W: Chicken Manure + Poplar Sawdust and Shaving, HL Horse Manure, G-W: Goat Manure + Poplar Sawdust and Shaving, G-O: Goat Manure + Olive Press Cake, ChL-O: Chicken Manure + Olive Press Cake, Gr: Solid Grape Waste. For Each Parameter, Different Letters Indicate Significant Differences Among Treatments (n=3; Tukey Test P>0.05). TOC: Total Organic C

\begin{tabular}{|c|c|c|c|c|c|c|}
\hline & ChL-W & HL & G-W & G-O & ChL-O & Gr \\
\hline Conductivity $\left(\mathrm{dS} \mathrm{m}^{-1}\right)$ & $4.17 \mathrm{~b}$ & $2.10 \mathrm{c}$ & $7.36 \mathrm{a}$ & $2.25 \mathrm{c}$ & $1.30 \mathrm{~d}$ & $0.25 \mathrm{e}$ \\
\hline $\mathrm{pH}$ & $7.05 \mathrm{c}$ & $9.19 \mathrm{a}$ & $9.09 \mathrm{a}$ & $8.56 \mathrm{~b}$ & $7.80 \mathrm{~b}$ & $6.87 \mathrm{c}$ \\
\hline TOC $\left(\mathrm{g} \mathrm{kg}^{-1}\right)$ & $266.2 \mathrm{c}$ & $333.2 \mathrm{~b}$ & $349.2 \mathrm{~b}$ & $443.6 \mathrm{a}$ & $373.4 \mathrm{~b}$ & $482.3 \mathrm{a}$ \\
\hline Soluble $\mathrm{C}\left(\mathrm{g} \mathrm{kg}^{-1}\right)$ & $5.8 \mathrm{a}$ & $4.7 \mathrm{a}$ & $6.2 \mathrm{a}$ & $2.5 \mathrm{~b}$ & $1.1 \mathrm{~b}$ & $1.5 \mathrm{~b}$ \\
\hline Lignin (\%) & $6.6 \mathrm{c}$ & $2.0 \mathrm{~d}$ & $1.8 \mathrm{~d}$ & $29.4 \mathrm{~b}$ & $41.0 \mathrm{a}$ & $50.0 \mathrm{a}$ \\
\hline Cellulose (\%) & $39.0 \mathrm{a}$ & $46.01 \mathrm{a}$ & $42.23 \mathrm{a}$ & $38.77 \mathrm{a}$ & $17.46 \mathrm{~b}$ & $20.90 \mathrm{~b}$ \\
\hline Total N $\left(\mathrm{g} \mathrm{kg}^{-1}\right)$ & $16.1 \mathrm{~b}$ & $12.0 \mathrm{c}$ & $18.3 \mathrm{ab}$ & $16.7 \mathrm{~b}$ & $19.5 \mathrm{ab}$ & $23.1 \mathrm{a}$ \\
\hline $\mathrm{NO}_{3}\left(\mathrm{mg} \mathrm{kg}^{-1}\right)$ & $187 \mathrm{~b}$ & $191 \mathrm{~b}$ & $363 \mathrm{a}$ & $104 \mathrm{c}$ & $49 \mathrm{~d}$ & $38 \mathrm{~d}$ \\
\hline $\mathrm{NH}_{4}\left(\mathrm{mg} \mathrm{kg}^{-1}\right)$ & $195 \mathrm{a}$ & $38 \mathrm{c}$ & $161 \mathrm{a}$ & $32 \mathrm{c}$ & $27 \mathrm{c}$ & $62 \mathrm{~b}$ \\
\hline $\mathrm{C} / \mathrm{N}$ & $16.53 \mathrm{~b}$ & $27.76 \mathrm{a}$ & $19.08 \mathrm{ab}$ & $26.56 \mathrm{a}$ & $19.14 \mathrm{ab}$ & $20.88 \mathrm{ab}$ \\
\hline $\mathrm{K}\left(\mathrm{g} \mathrm{kg}^{-1}\right)$ & $11.8 \mathrm{~b}$ & $11.9 \mathrm{~b}$ & $23.8 \mathrm{a}$ & $9.0 \mathrm{~b}$ & $5.3 \mathrm{c}$ & $2.8 \mathrm{c}$ \\
\hline $\mathrm{Na}\left(\mathrm{g} \mathrm{kg}^{-1}\right)$ & $6.8 \mathrm{~b}$ & $2.1 \mathrm{c}$ & $20.5 \mathrm{a}$ & $6.6 \mathrm{~b}$ & $3.5 \mathrm{c}$ & $1.2 \mathrm{c}$ \\
\hline $\mathrm{Zn}\left(\mathrm{mg} \mathrm{kg}^{-1}\right)$ & $638.5 \mathrm{a}$ & $215.0 \mathrm{~d}$ & $352.5 \mathrm{c}$ & $276.5 \mathrm{~d}$ & $458.0 \mathrm{~b}$ & $229.0 \mathrm{~d}$ \\
\hline $\mathrm{Pb}\left(\mathrm{mg} \mathrm{kg}^{-1}\right)$ & $32.05 \mathrm{a}$ & $23.05 \mathrm{~b}$ & $27.50 \mathrm{a}$ & $21.80 \mathrm{~b}$ & $13.25 \mathrm{c}$ & $2.15 \mathrm{~d}$ \\
\hline $\mathrm{Cd}\left(\mathrm{mg} \mathrm{kg}^{-1}\right)$ & $3.08 \mathrm{a}$ & $1.90 \mathrm{~b}$ & $1.68 \mathrm{~b}$ & $1.25 \mathrm{~b}$ & $1.90 \mathrm{~b}$ & $1.10 \mathrm{~b}$ \\
\hline $\mathrm{Cu}\left(\mathrm{mg} \mathrm{kg}^{-1}\right)$ & $96.15 \mathrm{a}$ & $80.00 \mathrm{a}$ & $41.60 \mathrm{~b}$ & $41.20 \mathrm{~b}$ & $101.5 \mathrm{a}$ & $91.40 \mathrm{a}$ \\
\hline
\end{tabular}

Table 3. Microbial Characteristics of Composting Materials from All Treatments at the Hydrolytic Stage. ChL-W: Chicken Manure + Poplar Sawdust and Shaving, HL Horse Manure, G-W: Goat Manure + Poplar Sawdust and Shaving, G-O: Goat Manure + olive Press Cake, ChL-O: Chicken Manure + Olive Press Cake, Gr: Solid Grape Waste. For Each Parameter, Different Letters Indicate Significant Differences Among Treatments (n=3; Tukey Test $\mathbf{P}>0.05)$

\begin{tabular}{|c|c|c|c|c|c|c|}
\hline$\left(\log \mathrm{g}^{-1}\right)$ & ChL-W & HL & G-W & G-O & ChL-O & Gr \\
\hline Saccharolytic fungi & $3.06 \mathrm{~b}$ & $3.07 \mathrm{~b}$ & $4.01 \mathrm{~b}$ & $5.15 \mathrm{a}$ & $6.23 \mathrm{a}$ & $6.63 \mathrm{a}$ \\
\hline Ammonifiers & $5.61 \mathrm{c}$ & $5.48 \mathrm{c}$ & $8.31 \mathrm{a}$ & $7.87 \mathrm{a}$ & $4.82 \mathrm{c}$ & $7.04 \mathrm{~b}$ \\
\hline $\mathrm{N}_{2}$ fixers & $9.59 \mathrm{a}$ & $9.82 \mathrm{a}$ & $7.32 \mathrm{c}$ & $8.46 \mathrm{~b}$ & $9.55 \mathrm{a}$ & $9.67 \mathrm{a}$ \\
\hline Cellulolytics & $10.61 \mathrm{a}$ & $7.65 \mathrm{~b}$ & $11.18 \mathrm{a}$ & $7.65 \mathrm{~b}$ & $5.48 \mathrm{c}$ & $6.40 \mathrm{~b}$ \\
\hline Nitrifiers & $2.88 \mathrm{~b}$ & $3.65 \mathrm{a}$ & $4.04 \mathrm{a}$ & $2.18 \mathrm{~b}$ & $2.60 \mathrm{~b}$ & $1.95 \mathrm{~b}$ \\
\hline
\end{tabular}

$\mathrm{P}\left(15.0 \mathrm{~g} \mathrm{~kg}^{-1}\right), \mathrm{Ca}\left(135.2 \mathrm{~g} \mathrm{~kg}^{-1}\right), \mathrm{Zn}, \mathrm{Pb}$, and $\mathrm{Cd}$, and the lowest values of TOC and fulvic acids (Table 4).

In general, the remaining treatments exhibited intermediate values, except G-W, which exhibited the highest values of moisture (54.46\%), conductivity, fulvic acids, $\mathrm{Mg}(10.2 \mathrm{~g}$ $\mathrm{kg}^{-1}$ ), $\mathrm{K}$, and $\mathrm{Na}$ (Table 4). As in samples taken at the hydrolytic stage, no treatment showed $\mathrm{Cr}$ or $\mathrm{Ni}$. Stability indices differed significantly between treatments. Gr had the highest ammonium/nitrate values whereas the highest records of HI and HT were observed in ChL-W, and the lowest HT value was found in G-W (Table 4).
Biological characteristics of WC also varied significantly between treatments and did not exhibit a general pattern. The highest abundance values were recorded in $\mathrm{Gr}$ treatment, with high amount of saccharolytic fungi and N-fixers, and in ChL-O, with high amount of ammonifiers, cellulolytics and nitrifiers. By contrast, the lowest values were recorded in ChL-W, with low abundance of fixers and nitrifiers, and in G-W, with low abundance of ammonifiers and saccharolytic fungi (but similar to HL). As in the hydrolytic stage, E. coli and Salmonella spp. were not detected in any treatment (Table 5). 
Table 4. Chemical Characteristics of Windrow-Composted Products from All Treatments. ChL-W: Chicken Manure + Poplar Sawdust and Shaving, HL Horse Manure, G-W: Goat Manure + Poplar Sawdust and Shaving, G-O: Goat Manure + Olive Press Cake, ChL-O: Chicken Manure + Olive Press cake, Gr: Solid Grape Waste. For Each Parameter, Different Letters Indicate Significant Differences Among Treatments (n=3; Tukey Test P>0.05). TOC: Total Organic C; HI: Humification Index; HT: Polymerization Degree

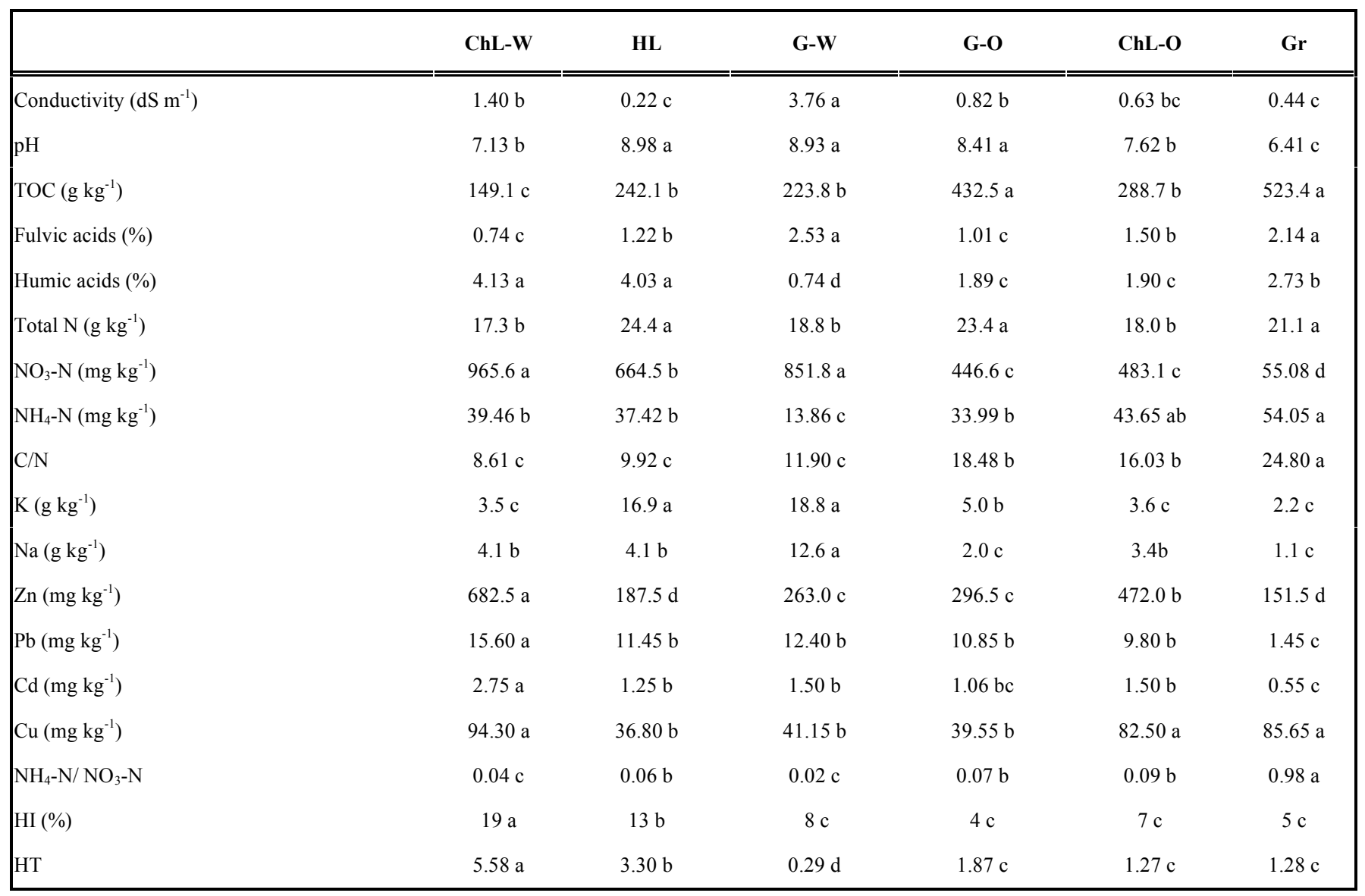

Table 5. Microbial Characteristics of Windrow-Composted Products from All Treatments. ChL-W: Chicken Manure + Poplar Sawdust and Shaving, HL Horse Manure, G-W: Goat Manure + Poplar Sawdust and Shaving, G-O: Goat Manure + Olive Press Cake, ChL-O: Chicken Manure + Olive Press Cake, Gr: Solid Grape Waste. For Each Parameter, Different Letters Indicate Significant Differences Among Treatments (n=3; Tukey Test $\mathbf{P}>0.05)$

\begin{tabular}{|c|c|c|c|c|c|c|}
\hline$\left(\log \mathrm{g}^{-1}\right)$ & ChL-W & HL & G-W & G-O & ChL-O & Gr \\
\hline Saccharolytic fungi & $0.48 \mathrm{~b}$ & $0.00 \mathrm{c}$ & $0.00 \mathrm{c}$ & $0.90 \mathrm{~b}$ & $1.67 \mathrm{ab}$ & $2.13 \mathrm{a}$ \\
\hline $\mathrm{N}_{2}$ fixers & $0.00 \mathrm{c}$ & $3.01 \mathrm{~b}$ & $3.93 \mathrm{~b}$ & $3.32 \mathrm{~b}$ & $3.33 \mathrm{~b}$ & $4.61 \mathrm{a}$ \\
\hline Cellulolytics & $3.65 \mathrm{ab}$ & $3.04 \mathrm{~b}$ & $3.18 \mathrm{~b}$ & $2.48 \mathrm{c}$ & $4.48 \mathrm{a}$ & $3.21 \mathrm{~b}$ \\
\hline
\end{tabular}

The structure of microbial communities was very different between treatments. In all treatments ammonifiers were the dominant population, except in ChL-W (with a dominance of cellulolytics: $41 \%$ ) and G-W (with a dominance of fixers: $32 \%$ ). Moreover, three treatments lacked one of the population groups: no saccharolytic fungi were detected in HL and G-W, whereas no N-fixers were detected in ChL-W (Fig. 1b).

\section{Chemical and Biological Characteristics of Vermicom- posted Products (VC)}

As in WC products, all chemical variables of vermicomposted products were significantly different among treatments, except for $\mathrm{Na}$ content. Treatments $\mathrm{ChL}-\mathrm{W}$ and $\mathrm{Gr}$ exhibited the highest humic acid values. ChL-W exhibited the highest content of $\mathrm{P}\left(15.4 \mathrm{~g} \mathrm{~kg}^{-1}\right), \mathrm{Ca}\left(114.9 \mathrm{~g} \mathrm{~kg}^{-1}\right)$, and 

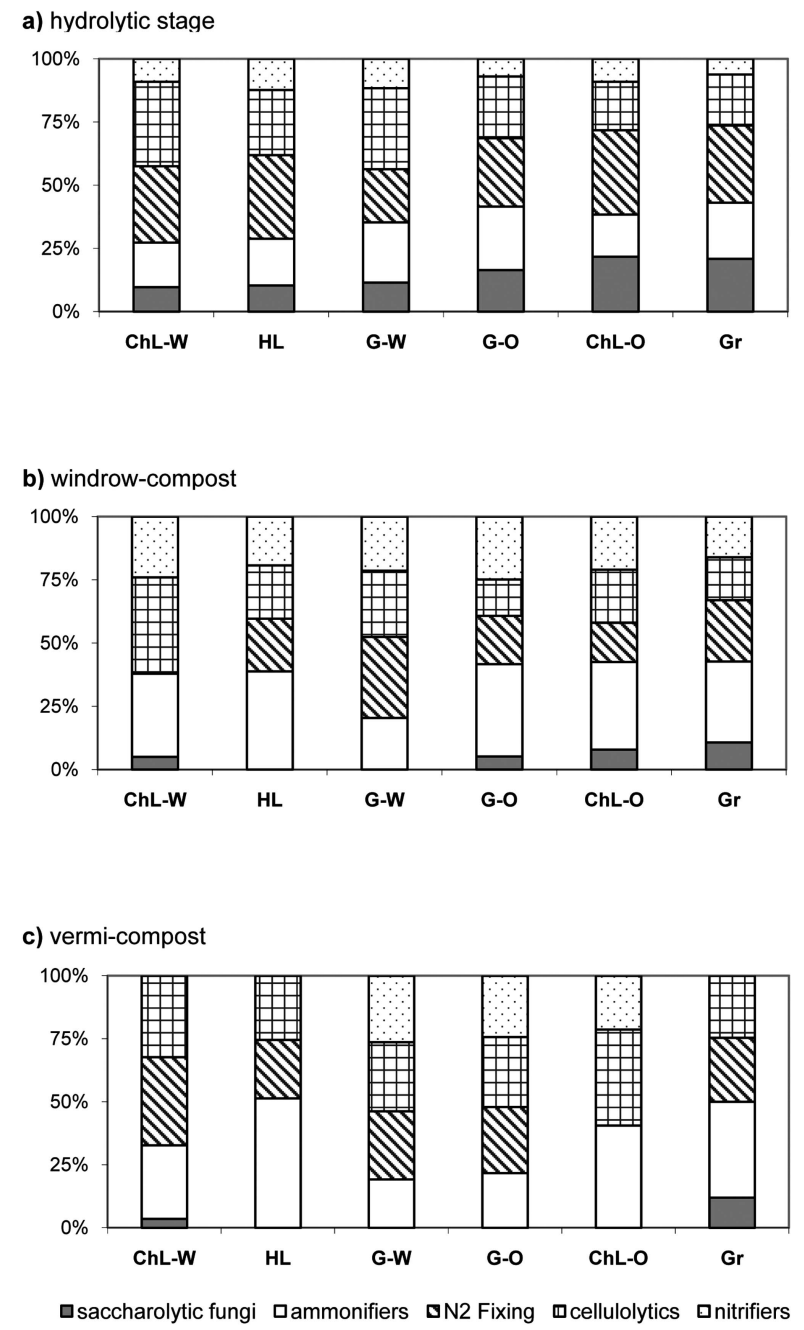

Fig. (1). Microbial community structure (relative abundance, \%) at the hydrolytic stage and windrow-composted and vermicomposted products from all treatments. ChL-W: chicken manure + poplar sawdust and shaving, HL horse manure + olive press cake, manure, G-W: goat manure + poplar sawdust and shaving, G-O: goat ChL-O: chicken manure + olive press cake, Gr: solid grape waste.

$\mathrm{Zn}$, and Gr presented the highest values of TOC and total N, and the lowest values of nitrate, $\mathrm{P}\left(0.9 \mathrm{~g} \mathrm{~kg}^{-1}\right)$ and $\mathrm{Ca}(15.0 \mathrm{~g}$ $\left.\mathrm{kg}^{-1}\right)$. Treatment HL had the highest values of conductivity, ammonium, and $\mathrm{K}$, and the lowest values of $\mathrm{Cu}$. Treatment G-O exhibited the highest values of fulvic acids and the lowest of humic acids. The remaining treatments exhibited intermediate values and there were no records of $\mathrm{Cr}$ or $\mathrm{Ni}$ (Table 6).

Stabilization/maturity indices also differed significantly among treatments. The ChL-O and Gr showed higher ammonium/nitrate ratio than the remaining treatments. By contrast, the highest IH and HT values were recorded in ChL-W, whereas the lowest HT value was detected in G-O (Table 6).

All biological variables differed among treatments, without following a regular pattern. Gr had the highest value of saccharolytic fungi; HL had the lowest value of ammonifiers; G-W exhibited the lowest value of fixers (similar to $\mathrm{Gr}$ ) and nitrifiers; and treatment ChL-O had the lowest cellulolytic value. The lowest abundance values were recorded erratically in all treatments (e.g., nitrifiers were nondetectable in ChL-W, HL, and Gr) (Table 7).

Structure of microbial communities was also very different among treatments. Ammonifiers were dominant in HL,
ChL-O, and Gr, whereas cellulolytics prevailed in G-W and $\mathrm{G}-\mathrm{O}$, and N-fixers and cellulolytics were dominant in ChL$\mathrm{W}$ (Fig. 1c). None of the treatments maintained the five population groups: $\mathrm{ChL}-\mathrm{W}$ and $\mathrm{Gr}$ did not present nitrifiers, G-W and G-O did not exhibit saccharolytic fungi or nitrifiers; in the remaining treatments, two groups were absent: saccharolytic fungi and nitrifiers in $\mathrm{HK}$, and saccharolytic fungi and fixers in ChL-O (Fig. 1c).

\section{Dynamics of Microbial Functional Groups}

The abundance of microbial groups analyzed varied significantly between the hydrolytic stage and the final products (WC and VC), but the pattern differed among treatments and products. N-fixers, saccharolytic fungi, and cellulolytics decreased in all treatments and products $(\mathrm{P}<0.05)$, although to different degrees (Fig. 2a, d, and e), whereas groups related to $\mathrm{N}$ availability exhibited a very different behaviour depending on the starting mixture and finished products.

In WC, ammonifiers increased in ChL-O $(53 \% ; \mathrm{P}=$ 0.001 ), did not vary in $\mathrm{HL}, \mathrm{Gr}$ and $\mathrm{G}-\mathrm{O}$ and decreased in the remaining treatments, whereas in $\mathrm{VC}$, ammonifiers did not vary in HL and ChL-O and decreasing in the remaining treatments (Fig. 2c). By contrast, nitrifiers, behaved in a very 
Table 6. Chemical Characteristics of Vermicomposted Products from All Treatments. ChL-W: Chicken Manure + Poplar Sawdust and Shaving, HL Horse Manure, G-W: Goat Manure + Poplar Sawdust and Shaving, G-O: Goat Manure + Olive Press Cake, ChL-O: Chicken Manure + Olive Press Cake, Gr: Solid Grape Waste. For Each Parameter, Different Letters Indicate Significant Differences Among Treatments (n=3; Tukey Test P>0.05). TOC: Total Organic C; HI: Humification Index; HT: Polymerization Degree

\begin{tabular}{|c|c|c|c|c|c|c|}
\hline Conductivity $\left(\mathrm{dS} \mathrm{m}^{-1}\right)$ & $0.84 \mathrm{ab}$ & $1.21 \mathrm{a}$ & $0.93 \mathrm{ab}$ & $0.49 \mathrm{~b}$ & $0.64 \mathrm{~b}$ & $0.48 \mathrm{~b}$ \\
\hline TOC $\left(\mathrm{g} \mathrm{kg}^{-1}\right)$ & $168.4 \mathrm{e}$ & $211.0 \mathrm{~d}$ & $266.6 \mathrm{~d}$ & $405.0 \mathrm{~b}$ & $343.4 \mathrm{c}$ & $478.9 \mathrm{a}$ \\
\hline Fulvic acids (\%) & $1.21 \mathrm{c}$ & $1.39 \mathrm{~b}$ & $1.58 \mathrm{~b}$ & $2.37 \mathrm{a}$ & $1.41 \mathrm{~b}$ & $1.54 \mathrm{~b}$ \\
\hline Total N ( $\left.\mathrm{g} \mathrm{kg}^{-1}\right)$ & $16.2 \mathrm{c}$ & $14.6 \mathrm{c}$ & $23.8 \mathrm{~b}$ & $19.7 \mathrm{c}$ & $15.0 \mathrm{c}$ & $36.6 \mathrm{a}$ \\
\hline $\mathrm{NO}_{3}-\mathrm{N}\left(\mathrm{mg} \mathrm{kg}^{-1}\right)$ & $809.4 \mathrm{a}$ & $169.1 \mathrm{c}$ & $791.0 \mathrm{a}$ & $300.6 \mathrm{~b}$ & $46.2 \mathrm{~d}$ & $49.7 \mathrm{~d}$ \\
\hline $\mathrm{NH}_{4}-\mathrm{N}\left(\mathrm{mg} \mathrm{kg}^{-1}\right)$ & $28.45 \mathrm{c}$ & $56.21 \mathrm{a}$ & $37.34 \mathrm{~b}$ & $27.72 \mathrm{c}$ & $45.00 \mathrm{ab}$ & $33.30 \mathrm{~b}$ \\
\hline $\mathrm{C} / \mathrm{N}$ & $10.39 \mathrm{c}$ & $14.45 \mathrm{~b}$ & $11.20 \mathrm{bc}$ & $22.55 \mathrm{a}$ & $22.86 \mathrm{a}$ & $13.08 \mathrm{~b}$ \\
\hline $\mathrm{Zn}\left(\mathrm{mg} \mathrm{kg}^{-1}\right)$ & $650.0 \mathrm{a}$ & $501.5 \mathrm{~b}$ & $371.5 \mathrm{c}$ & $293.5 \mathrm{c}$ & $559.5 \mathrm{ab}$ & $244.5 \mathrm{c}$ \\
\hline $\mathrm{Pb}\left(\mathrm{mg} \mathrm{kg}^{-1}\right)$ & $14.20 \mathrm{a}$ & $11.90 \mathrm{~b}$ & $14.85 \mathrm{a}$ & $10.70 \mathrm{~b}$ & $9.70 \mathrm{~b}$ & $1.85 \mathrm{c}$ \\
\hline $\mathrm{Cd}\left(\mathrm{mg} \mathrm{kg}^{-1}\right)$ & $2.20 \mathrm{a}$ & $1.20 \mathrm{~b}$ & $1.25 \mathrm{~b}$ & $0.90 \mathrm{bc}$ & $1.45 \mathrm{~b}$ & $0.25 \mathrm{c}$ \\
\hline $\mathrm{Cu}\left(\mathrm{mg} \mathrm{kg}^{-1}\right)$ & $87.50 \mathrm{a}$ & $30.30 \mathrm{~d}$ & $41.10 \mathrm{c}$ & $38.85 \mathrm{c}$ & $82.10 \mathrm{a}$ & $74.95 \mathrm{~b}$ \\
\hline $\mathrm{NH}_{4}-\mathrm{N} / \mathrm{NO}_{3}-\mathrm{N}$ & $0.03 \mathrm{c}$ & $0.33 \mathrm{~b}$ & $0.05 \mathrm{c}$ & $0.09 \mathrm{c}$ & $0.97 \mathrm{a}$ & $0.67 \mathrm{a}$ \\
\hline HI (\%) & $14 \mathrm{a}$ & $10 \mathrm{ab}$ & $9 \mathrm{~b}$ & $5 \mathrm{~b}$ & $6 \mathrm{~b}$ & $5 \mathrm{~b}$ \\
\hline HT & $2.36 \mathrm{a}$ & $1.72 \mathrm{~b}$ & $1.56 \mathrm{~b}$ & $0.63 \mathrm{c}$ & $1.45 \mathrm{~b}$ & $1.81 \mathrm{~b}$ \\
\hline
\end{tabular}

Table 7. Microbial Characteristics of Vermicomposted Products from All Treatments. ChL-W: Chicken Manure + Poplar Sawdust and Shaving, HL Horse Manure, G-W: Goat Manure + Poplar Sawdust and Shaving, G-O: Goat Manure + Olive Press Cake, ChL-O: Chicken Manure + Olive Press Cake, Gr: Solid Grape Waste. For Each Parameter, Different Letters Indicate Significant Differences Among Treatments $(n=3$; Tukey Test $\mathbf{P}>0.05)$

\begin{tabular}{|c|c|c|c|c|c|c|}
\hline$\left(\log \mathrm{g}^{-1}\right)$ & ChL-W & HL & G-W & G-O & ChL-O & $\mathbf{G r}$ \\
\hline Saccharolytic fungi & $0.30 \mathrm{~b}$ & $0.00 \mathrm{c}$ & $0.00 \mathrm{c}$ & $0.00 \mathrm{c}$ & $0.00 \mathrm{c}$ & $1.56 \mathrm{a}$ \\
\hline $\mathrm{N}_{2}$ fixers & $2.97 \mathrm{~b}$ & $3.01 \mathrm{~b}$ & $3.48 \mathrm{a}$ & $3.02 \mathrm{~b}$ & $0.00 \mathrm{c}$ & $3.30 \mathrm{a}$ \\
\hline Cellulolytics & $2.78 \mathrm{c}$ & $3.30 \mathrm{~b}$ & $3.54 \mathrm{ab}$ & $3.18 \mathrm{~b}$ & $4.65 \mathrm{a}$ & $3.23 \mathrm{~b}$ \\
\hline
\end{tabular}

different manner. In WC, strong increases were detected in Gr (56\%; P=0.002), ChL-O (72\%; P=0.001), and G-O (97\%; $\mathrm{P}=0.001)$, and did not vary in the remaining treatments, whereas in VC half of the treatments decreased strongly $(>95 \%)$ and the other three treatments exhibited values similar to the hydrolytic stage (Fig. 2b).

\section{DISCUSSION}

Chemical characteristics of materials observed immediately after the thermophilic sanitisation phase are consistent with several works in two key aspects: a) the range of values and $b)$ the wide variation in the data depending on the starting materials. For example, the TOC values we recorded (26 to $48 \%$ ) are consistent with the lowest values detected by Defrieri et al. [11] after 30 days of composting a mixture of horse litter and chicken litter (27.5\%) and the highest values found by Wang et al. [12] at 50 days of composting a mixture of dairy manure and oak sawdust (44\%). Similarly, total $\mathrm{N}$ values observed (1.2 to $2.3 \%$ ) are within the range of 
a)

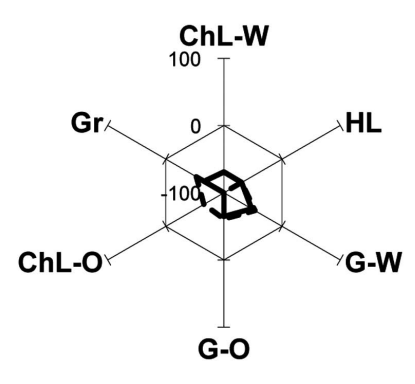

c)

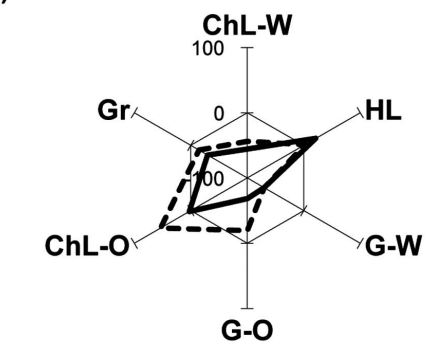

e)

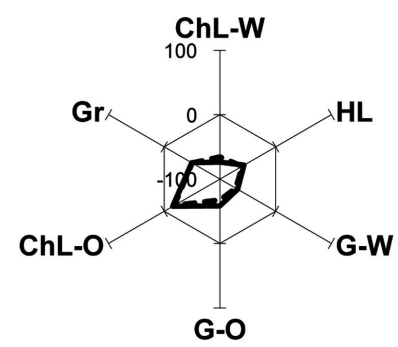

b)

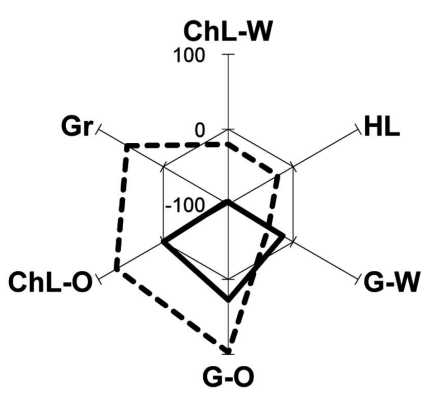

d)

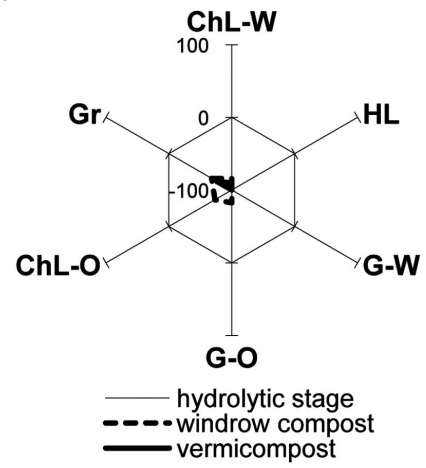

Fig. (2). Variations (\%) of the analyzed parameters between hydrolytic stage values (thin line) and windrow-composted (dashed line) and vermicomposted (thick line) products from all treatments. a) $\mathrm{N}_{2}$ fixers; b) nitrifiers; c) ammonifiers; d) saccharolytic fungi ; e) cellulolytics. ChL-W: chicken manure + poplar sawdust and shaving, HL horse manure, G-W: goat manure + poplar sawdust and shaving, G-O: goat manure + olive press cake, ChL-O: chicken manure + olive press cake, Gr: solid grape waste.

those mentioned by Wang et al. [12] for a mixture of dairy manure and wheat straw $(3.1 \%)$.

The heterogeneity found among treatments is particularly evident in the content of inorganic $\mathrm{N}$ fractions. The values we recorded vary by a factor of 10 , which agrees with variations in nitrates mentioned by Wang et al. [12] (between $<1$ $\mathrm{mg} \mathrm{kg}^{-1}$ in pig manure + oak shredded wood and $9.7 \mathrm{mg} \mathrm{kg}^{-1}$ in dairy manure + wheat straw). These authors, however, found a 30-times increase in ammonium content (between $123 \mathrm{mg} \mathrm{kg}^{-1}$ and $3780 \mathrm{mg} \mathrm{kg}^{-1}$ ) among treatments. The absence of pathogens immediately after the sanitization phase indicates that, although temperature did not reach the recommended value of $60{ }^{\circ} \mathrm{C}$ [5], sanitization was achieved in all treatments.

\section{Chemical Characteristics of Maturation/Stability Stan- dards}

There is an abundance of information about the chemical composition of finished products and its relationship with the state of maturity/stability and quality standards $[4,3,11,17$, $26]$. Under the conditions applied in this work with regard to time of maturation, the finished products would be mature/stable; but according to some maturity indicators pro- posed in the literature, not all of our finished products fulfil these indices. According to Guerra-Rodriguez et al. [27], compost products can be considered stable when total $\mathrm{N}$ increases and ammonium content decreases. Based on these criteria, only some of the WC we obtained would be mature (though partially). Treatments HL, GO, and Gr meet the stability requirements because total $\mathrm{N}$ increases; ChL-W and GW also meet the requirements because ammonium decreases.

Humification indices are widely used in the literature to estimate maturity state. If we take into account the humiclike substances/OM ratio, the values estimated in this work are within the ranges mentioned by Campitelli and Ceppi [28] (between 1.08 and 2.95) and Lopez et al. [29] (0.14), except in the windrow-composted treatment ChL-W, in which values exceed such ranges by a large amount (5.58). According to Iglesias-Jimenez and Perez-Garcia [30] however, only the treatments composted and vermicomposted ChL-W and composted HL would be mature, since they are above the minimum $13 \%$. Furthermore, if we consider the polymerization degree (HA/FA) an indicator, most of our products would be mature, since they exceed the threshold of 1.6 as defined by Iglesias-Jimenez and Perez-Garcia [30]. 
Therefore, according to these criteria, the treatments that would not be mature enough, are those that exhibit high fiber content at the hydrolytic stage i.e. windrow-composted G-W, ChL-O, and $\mathrm{Gr}$ and vemicomposted G-O, and ChL-O.

Another widely used maturity index is ammonium/nitrate ratio which, according to Defrieri et al. [11], should be below 0.16 ; in response to the decrease of ammonium and an increase of nitrification during maturation [3, 31]. According to this parameter, all our finished products would be mature, except for those that did not reach polymerization degree (vermicomposted and windrow-composted $\mathrm{Gr}$, and vermicomposted ChL-O). These results are consistent with those of Wang et al. [12], who did not find nitrate increased at the end of the composting process, with a starting material containing a high level of lignocellulosic compounds.

The differences in chemical maturity indices found between WC and VC are consistent with observations of Tognetti et al. [31], who employed production methods very similar to those we used in this work. These authors state that in achieving mature compost, the starting materials play a more important role than the type of maturation process.

All our products in general meet the quality standards of the EU (European Union), USEPA (United State Environmental Protection Agency), and of several countries [1, 32]; except for water content, which is higher than the threshold value (only windrow-composted ChL-W and $\mathrm{Gr}$ are below the $45 \%$ threshold of European standards). In addition, our products would be safe because they do not reach the maximum tolerable limits for heavy metal content and pathogens $[1,32]$.

Regarding the remaining parameters, our finished products are within the admissible ranges of $\mathrm{pH}(6.3-8.9)$, the minimum admissible levels for organic matter $(>20 \%)$, and total $\mathrm{N}(>0.8 \%)$, and the maximum tolerable limits for conductivity $(<5 \mathrm{dS} / \mathrm{m})$, ammonium content $\left(<400 \mathrm{mg} \mathrm{kg}^{-1}\right)$ and $\mathrm{C} / \mathrm{N}(<20)[1,27,33]$.

\section{Microbial Dynamics}

Our data on dynamics are consistent with the few studies whose authors report that analyzed microbial groups involved in composted waste. For example, Corlay-Chee et al. [6] and Jouraiphy et al. [25] also found a decrease in saccharolytic fungi at the end of the composting process. Santamaria-Romero et al. [15] however, did not detect a decrease in cellulolytics at the end of composting, although they also found an increase in abundance of fixing organisms at the hydrolytic stage.

The high number of $\mathrm{N}$-fixing organisms (also the dominant population in almost all treatments) in the sanitised output might be related to the final increase of TN detected in some cases. This finding is in agreement with SantamaríaRomero et al. [15], who found a significant correlation between fixing organisms and total $\mathrm{N}$ content. Our results are also in agreement with findings reported by Plaza et al. [34], who state that an increase of $\mathrm{N}$ in compost might be due to $\mathrm{N}$ fixation. This idea is consistent with frequent observations in natural decomposition processes of plant residues [35].

Although there is minimal information on the abundance of functional groups in compost, studies on specific enzyme activity can be used for comparison purposes. For example, the decrease in the abundance of ammonifiers at the final stage of maturation is in agreement with works reporting a greater protease and urease activity at the start of composting, than later in the process $[3,11]$. Similarly, the decrease in saccharolytic fungi at the end of composting agrees with the use of monomeric sugar at the hydrolytic stage reported by Steger et al. [9].

Overall, microbial dynamics observed in this work are correlated with the chemical characteristics of the starting materials. For example, the correlation of saccharolytic fungi (negative with soluble $\mathrm{C}, \mathrm{r}=-0.63$; positive with fibers; $\mathrm{r}=$ 0.75 ) indicate that when the amount of monomers in the starting materials is high, monomers are metabolized rapidly. By contrast, when the amount of fiber is high, monomers are gradually released, allowing the persistence of saccharolytic fungi until the end of the process [8].

This criterion also holds for the persistence of cellulolytics to the end of composting in the treatments with high amounts of fibers at the hydrolytic stage (G-O and Gr). This result agrees with findings of Vinceslas-Akpa and Loquet [36] in that materials with high lignocellulolytic content require more than 10 months for degradation.

The correlations between the chemical and biological variables of the finished products also explain several aspects of microbial dynamics. For example, the correlation of ammonifiers with ammonium content in both maturation processes ( $\mathrm{WC}, \mathrm{r}=0.78$ and $\mathrm{VC} \mathrm{r}=0.84$ ) explains the variation in the nitrate/ammonium ratio among treatments. The increase of ammonifiers at the end of maturation in ChL-O indicates that organic $\mathrm{N}$ compounds still persist. This is in agreement with observations reported by Ntougias et al. [33], who found high levels of ammonium in compost derived from olive waste.

Several works report results that are not consistent with respect to microbial characteristics in composting processes $[9,17]$. One of the most remarkable reports is that of Ntougias et al. [33], who observed a large amount of biomass and high microbial respiration but little hydrolytic activity (fluorescein acetate). This might be because the fluorescein acetate activity fails to detect metabolisms that oxidise inorganic compounds and consume $\mathrm{O}_{2}$. Such is the case of nitrifiers, which present a high nitrifying activity at the end of the degradation process of plant residues [31].

\section{Differences Between Windrow-Compost and Vermicom- post Products}

The differences in population dynamics found between WC and VC products are consistent with many reports in the literature regarding the effect of earthworms on microbial populations. According to Aira et al. [16], because of their grazing activity, earthworms have a negative effect on abundance of microorganisms. This finding explains the observation that in our finished products, abundance of microbial populations in VC was always lower than in WC.

Furthermore, differences in community structure between WC and VC might be due to the origin of microorganisms recolonizing materials during the maturation process. According to Fracchia et al. [37], airborne (usually sporulated) microorganisms prevail in compost after the thermophilic 
stage, whereas in VC soil microorganisms prevail due to earthworm activities (digging and feeding). Likewise, the low abundance of nitrifiers in VC might be explained by the low level of ammonium available due to the incorporation of earthworms in the biomass [3].

\section{Fertility Indicators}

Because the results are so heterogeneous, proposing some populations as universal indicators of the degree of compost fertility is difficult. Even if some indices are calculated by combining chemical and biological parameters, neither constant values nor a general pattern is obtained. The indices of similar range are: a) ammonium/ammonifiers ratio (a degradation degree indicator of $\mathrm{N}$ organic compounds): 515 , and b) cellulolytics/humic substances ratio (an indicator of the balance between degradation and synthesis of polymerized compounds): 0.57-1.36.

From this perspective, our results agree with the findings of other authors, like Tognetti et al. [31] and Kalamdhad et al. [26], in that although several advances have been made to determine stability and quality indices, none of these indices has been universally accepted, because all the parameters proposed are highly dependent on the starting materials.

However, the microbial community structure might be used as a maturity index. This is because the products that best fulfilled the chemical stability parameters are those that reduced the number of populations in its community. By contrast, the products that still maintain all the original populations (such as Gr) are those that are still not mature enough. Following this criterion, $\mathrm{VC}$ would be more mature than $\mathrm{WC}$, in correlation with the longer time of maturation (180 vs 140 days).

In summary, we consider that our results are an original contribution to the knowledge and management of the different waste materials used for composting. Because the microbial abundance analysis uses easy and precise techniques, they can be a valid tool for determining the compost maturity from different starting materials.

\section{ACKNOWLEDGEMENTS}

Financial support was provided to MFF by Secretaria de Ciencia, Tecnica y Posgrado, Universidad Nacional de Cuyo, Argentina.

\section{REFERENCES}

[1] Lasaridi K, Protopapa I, Kotsou M, Pilidis G, Manios T, Kyriacou A. Quality assessment of composts in the Greek market: The need for standards and quality assurance. J Environ Manage 2006; 80: 58-65.

[2] Insam H, Amor K, Renner M, Crepaz C. Changes in functional abilities of the microbial community during composting of manure. Microb Ecol 1996; 31: 77-87.

[3] Benítez E, Nogales R, Elvira C, Masciandaro G, Ceccanti B. Enzyme activities as indicators of the stabilization of sewage sludges composting with Eisenia foetida. Bioresour Technol 1999; 67: 297-303.

[4] Baffi C, Dell'Abate MT, Nassisi A, et al. Determination of biological stability in compost: A comparison of methodologies. Soil Biol Biochem 2007; 39: 1284-93.

[5] Frederickson J, Butt KR, Morris RM, Daniel C. Combining vermiculture with traditional green waste composting systems. Soil Biol Biochem 1997; 29: 725-30.
[6] Corlay-Chee L, Ferrera-Cerrato R, Elchevers-Barra JD, EchegarayAleman A, Santizo-Rincon JA. Cinética de grupos microbianos en el proceso de producción de composta y vermicomposta. Agrociencia $1999 ; 33: 375-80$.

[7] Sanchez-Monedero MA, Roig A, Cegarra J, Bernal MP. Relationships between water-soluble carbohydrate and phenol fractions and the humification indices of different organic wastes during composting. Bioresour Technol 1999; 70: 193-201.

[8] Said-Pullicino D, Erriquens FG, Gigliotti G. Changes in the chemical characteristics of water-extractable organic matter during composting and their influence on compost stability and maturity. Bioresour Technol 2007; 98: 1822-31.

[9] Steger K, Eklind Y, Olsson J, Sundh I. Microbial community growth and utilization of carbon constituents during thermophilic composting at different oxygen levels. Microb Ecol 2005; 50: 163 71.

[10] Mondini C, Dell' Abate MT, Leita L, Benedetti A. An integrated chemical, thermal, and microbiological approach to compost stability evaluation. J Environ Qual 2003; 32: 2379-86.

[11] Defrieri RL, Jiménez D, Effron MP, Palma M. Utilización de parámetros químicos y microbiologicos como criterios de madurez durante el proceso de compostaje. Agriscientia 2005; 22: 25-31.

[12] Wang P, Changa CM, Watson ME, Dick WA, Chen Y, Hoitink HAJ. Maturity indices for composted dairy and pig manures. Soil Biol Biochem 2004; 36: 767-76.

[13] Patra AK, Abbadie L, Caliz-Josserand A, et al. Effects of grazing on microbial functional groups involved in soil $\mathrm{N}$ dynamics. Ecol Monogr 2005; 75: 65-80.

[14] Abril A. Are soil microorganisms good indicators of land-use impact in ecosystems? Ecol Aust 2003; 13:195-204

[15] Santamaría-Romero S, Ferrera-Cerrato R, Almaraz-Suarez JJ, Galvis-Spinola A, Barois-Boullard I. Dinámica y relaciones de microorganismos, C-orgánico y N-total durante el composteo y vermicomposteo. Agrociencia 2001; 35: 377-84.

[16] Aira M, Monroy F, Domínguez J, Mato S. How earthworm density affects microbial biomass and activity in pig manure. Eur J Soil Biol 2002; 38: 7-10.

[17] Barragan-Sanchez J, Quiroga-Alonso JM, Coello-Oviedo MD. Use of microbial activity parameters for determination of a biosolid stability index. Bioresour Technol 2006; 97: 562-8.

[18] Nelson DW, Sommers LE. Total carbon, organic carbon and organic matter. In: Page AL, Miller R, Keeney D, Eds. Methods of Soil Analysis. Chemical and Microbiological Properties. American Society of Agronomy and Soil Science: Madison 1982; Vol. 2: pp. 539-80.

[19] Lorch HJ, Benckieser G, Ottow JCG. Basic methods for counting microorganisms in soil and water. In: Alef K, Nannipieri P, Eds. Methods in Applied Soil Microbiology and Biochemistry. Academic Press: London 1995; pp. 146-61.

[20] Döbereiner, J. Isolation and identification of aerobic nitrogen fixing bacteria from soil and plants. In: Alef K, Nannipieri P, Eds. Methods in Applied Soil Microbiology and Biochemistry. Academic Press: London 1995; pp. 134-41.

[21] USEPA. Methods of Chemical Analysis of Water and Wastes. Environmental Protection Agency. Center for Environmental Research Information: Cincinati 1999.

[22] Robertson GP, Coleman DC, Bledsoe CS, Sollins P. Standard Soil Methods for Long-term Ecological Research. Oxford University Press: New York 1999.

[23] Asp NG, Claes JG, Hallmer H, Siljestrom M. Rapid enzymatic assay of insoluble and soluble dietary fiber. J Agric Food Chem 1983; 31: 76-482.

[24] Page AL, Miller R, Keeney D. Methods of Soil Analysis. Vol 2. Chemical and Microbiological Properties. American Society of Agronomy and Soil Science: Madison 1982.

[25] Jouraiphy A, Amir S, El Gharous M, Revel JC, Hafidi M. Chemical and spectroscopic analysis of organic matter transformation during composting of sewage sludge and green plant waste. Int Biodeterior Biodegrad 2005; 56: 101-8.

[26] Kalamdhad AS, Pasha M, Kazmi AA. Stability evaluation of compost by respiration techniques in a rotary drum composter. Resour Conserv Recycl 2008; 52: 829-34.

[27] Guerra-Rodriguez E, Vázquez M, Diaz-Ravina M. Dynamics of physicochemical and biological parameters during the cocomposting of chestnut burr/leaf litter with solid poultry manure. J Sci Food Agric 2001; 81: 648-52. 
[28] Campitelli P, Ceppi S. Chemical, physical and biological compost and vermicompost characterization: A chemometric study. Chemometr Intell Lab Syst 2008; 90: 64-71.

[29] Lopez MJ, Vargas-Garcia MDC, Suarez-Estrella F, Moreno J. Biodelignification and humification of horticultural plant residues by fungi. Int Biodeterior Biodegrad 2006; 57: 24-30.

[30] Iglesias-Jimenez E, Perez-Garcia V. Determination of maturity indices for city refuse composts. Agric Ecosyst Environ 1992; 38 : 331-43.

[31] Tognetti C, Mazzarino MJ, Laos F. Cocomposting biosolids and municipal organic waste: effects of process management on stabilization and quality. Biol Fertil Soils 2007; 43: 387-97.

[32] Das KC, Smith MC, Gattie DK, Hale-Boothe DD. Stability and quality of municipal solid waste compost from a landfill aerobic bioreduction process. Adv Environ Res 2002; 6: 401-9.

[33] Ntougias S, Ehaliotis C, Papadopoulou KK, Zervakis G. Application of respiration and FDA hydrolysis measurements for estimating microbial activity during composting processes. Biol Fertil Soils 2006; 42: 330-7.
[34] Plaza C, Nogales R, Senesi N, Benitez E, Polo A. Organic matter humification by vermicomposting of cattle manure alone and mixed with two-phase olive pomace. Bioresour Technol 2008; 99: 5085-9.

[35] Abril A, Noé L, Casado-Murillo N, Kopp S. Non-symbiotic $\mathrm{N}_{2}$ fixation in soil, litter and phyllosphere in the arid-semiarid region of central Argentina. In: Couto GN, Ed. Nitrogen Fixation Research Progress. Nova Science Publishers: New York 2008; pp. 457-69.

[36] Vinceslas-Akpa M, Loquet M. Organic matter transformations in lignocellulosic waste products composted or vermicomposted (Eisenia faetida Andrei): chemical analysis and ${ }^{13} \mathrm{C}$ CPMAS NMR spectroscopy. Soil Biol Biochem 1997; 29: 751-8.

[37] Fracchia L, Dohrmann AB, Martinotti MG, Tebbe CC. Bacterial diversity in a finished compost and vermicompost: differences revealed by cultivation-independent analyses of PCR- amplified $16 \mathrm{~S}$ rRNA genes. Appl Microbiol Biotechnol 2006; 71: 942-52.

(C) Abril et al.; Licensee Bentham Open.

This is an open access article licensed under the terms of the Creative Commons Attribution Non-Commercial License (http://creativecommons.org/licenses/by-nc/3.0/) which permits unrestricted, non-commercial use, distribution and reproduction in any medium, provided the work is properly cited. 